\title{
Development of A Multi-Scheme Energy Management Strategy For A Hybrid Fuel Cell Driven Passenger Ship
}

\author{
Ameen M. Bassam ${ }^{\mathrm{a}, \mathrm{b}, *}$, Alexander B. Phillips ${ }^{\mathrm{c}}$, Stephen R. Turnock ${ }^{\mathrm{a}}$, Philip A. Wilson ${ }^{\mathrm{a}}$ \\ ${ }^{a}$ Fluid Structure Interactions Group, University of Southampton, Boldrewood Innovation Campus, SO16 7QF, UK \\ ${ }^{b}$ Naval Architecture and Marine Engineering Department, Faculty of Engineering, Port Said University, Port Fouad, Egypt \\ ${ }^{c}$ National Oceanography Centre, Natural Environment Research Council, UK
}

\begin{abstract}
Hybrid fuel cell propulsion systems for marine applications are attracting widespread interest due to the need to reduce ship emissions. In order to increase the potential of these systems, the design of an efficient energy management strategy (EMS) is essential to distribute the required power properly between different components of the hybrid system. For a hybrid fuel cell/battery passenger ship, a multi-scheme energy managements strategy is proposed. This strategy is developed using four schemes which are: state-based EMS, equivalent fuel consumption minimization strategy (ECMS), charge-depleting charge-sustaining (CDCS) EMS, the classical proportional-integral (PI) controller based EMS, in addition to a code that chooses the suitable scheme according to the simulation inputs. The main objective of the proposed multi-scheme EMS is to minimize the total consumed energy of the hybrid system in order to increase the energy efficiency of the ship.

The world's first fuel cell passenger ship FCS Alsterwasser is considered and its hybrid propulsion system is modelled in MATLAB/Simulink environment. The performance of the developed multi-scheme EMS is compared to the four studied strategies in terms of total consumed energy, hydrogen consumption, total cost and the stresses seen by the hybrid fuel cell/battery system components considering a daily ship operation of 8 hours. Results indicate that a maximum energy and hydrogen consumption savings of $8 \%$ and $16.7 \%$ respectively can be achieved using the proposed multi-scheme strategy.
\end{abstract}

Keywords: Multi-Scheme Energy Management Strategy, Hybrid Power System, Fuel Cell, PEMFC, MATLAB, Simulink

\section{Introduction}

The minimization of the negative environmental impacts of shipping and improving ships energy efficiency have generated considerable recent research interest. This concern is enhanced by the introduction of more stringent environmental regulations by the International Maritime Organization (IMO) to control ship emissions. Hybrid electric power and propulsion concepts have been suggested as an energy efficiency design index (EEDI) reduction measure adopted by the IMO to help ships to comply with the new international regulations [1, 2]. In order to make hybrid propulsion systems greener, fuel cells can be used in these systems as a main source of power 3 .

Proton exchange membrane fuel cell (PEMFC) has the advantages of zero emissions, quick start-up, high efficiency, high power density, low operating temperature, solid electrolyte, and low noise which promote the application of PEMFC in the transportation sector [4, 5]. A battery system is usually used as an energy storage technology

\footnotetext{
${ }^{*}$ Corresponding author

Email address: ab2e12@soton.ac.uk (Ameen M. Bassam )
}

to hybridize the fuel cell propulsion system in transportation applications in order to improve the efficiency of the fuel cell system and its dynamics 6 . The presence of the fuel cell and battery systems together requires an energy management strategy (EMS) to improve the electrical integration of the system.

Development of a suitable EMS is a basic issue for hybrid fuel cell propulsion systems to properly split the required power between the fuel cell and battery systems. EMS controls the dynamic behaviour of the hybrid system, its fuel consumption, and affects the system efficiency, weight, size, and lifetime of its components [7, 8]. Therefore, efforts have been made to investigate different EMS. These strategies may aim to minimize hydrogen consumption [9], maximize fuel cell efficiency or overall efficiency [10, reduce stresses on the hybrid system components [1], maintain battery state of charge (SOC) or the bus voltage at a certain level 19, 12, 13, minimize the operational cost [14] or minimize the hybrid system weight and size [8]. Whilst most of the studies about EMS give their attention to the hydrogen consumption, which is certainly important, in this paper more focus is concentrated on the total consumed energy taking into consideration the bat- 
tery depleted energy and the required energy to recharge the battery back to its initial SOC for the purpose of improving the energy efficiency of the examined ship. By taking the battery discharge energy during the voyage and the required energy to recharge it back to its initial SOC into account, the total consumed energy can be accurately obtained and different energy management strategies are fairly compared.

The literature review in the area of power distribution of hybrid fuel cell propulsion systems is dominated by automotive industry applications; however, there have been a few studies that investigated this problem for marine applications. In hybrid fuel cell propulsion systems, the fuel cell system can be used to supply the average required power in a load-levelling mode as suggested for small ships and underwater vehicles in [15, 16]. An alternative approach was proposed in [3] for a Korean tourist boat to use the fuel cell system in a load-following mode to provide the required power. Meanwhile, the battery system is used as a supplement to the fuel cell system and charged or discharged when the required load power is lower or higher than the available fuel cell power. For the hybrid fuel cell/battery passenger ship FCS Alsterwasser, a state-based EMS was developed in order to maximize the hybrid system efficiency [10]. Also, an improvement to the classical PI controller based EMS was presented in [17. for the FCS Alsterwasser that takes into account the fuel cell efficiency as an input to the EMS which results in reducing the fuel cell operational stress and its hydrogen consumption. A fuel cell/battery/ultra-capacitor hybrid power system was proposed for the same ship with a fuzzy logic EMS with an objective of enhancing the hybrid system performance 18 .

Due to the fact that each EMS has its main objective, there remains a need for using a multi-scheme EMS to improve the performance of hybrid fuel cell systems [11. This study represents a new approach to design an efficient multi-scheme EMS for hybrid fuel cell/battery propulsion systems of ships that have significant variation in its power demand. The approach used in this study aims to compare different energy management strategies at different battery SOC and different load levels for a hybrid fuel cell/battery passenger ship. This comparison is then used to develop a multi-scheme EMS for the first time that switches between different strategies during the voyage of the examined ship based on the battery SOC and the required load power in order to reduce the energy consumption of the hybrid fuel cell system and improve its energy efficiency. Four different EMS are implemented for the comparison which are: state-based EMS, equivalent fuel consumption minimization strategy (ECMS), charge-depleting charge-sustaining (CDCS) EMS, and the classical proportional-integral (PI) controller based EMS. These strategies are the most common and they are chosen for their simplicity and ease of realizability while other strategies are more complex and require longer computational time [11]. The four strategies are combined to develop a multi-scheme EMS with an ob- jective of minimizing the total consumed energy. Considering a daily operation of the ship of 8 hours, the five EMS are compared in terms of the consumed energy, hydrogen consumption, operational cost, and the stresses seen by the fuel cell and battery systems. Sensitivity analysis of different initial battery SOC as well as different energy prices are made to assess its effects on the results of the developed multi-scheme EMS.

The ship hybrid fuel cell propulsion system as well as different different energy management strategies are modelled in MATLAB/Simulink environment which is a flexible environment using the Simscape Power Systems (SPS) toolbox [19]. The paper is organized as follows. Section 2 introduces the examined ship and voyage. Section 3 describes different EMS while Section 4 illustrates the simulation implementation of the hybrid fuel cell propulsion system and different EMS. Section 5 shows the simulation results and discussion. Finally, Section 6 presents the work conclusions.

\section{Description of the ship \& voyage}

The world's first hydrogen fuel cell passenger ship FCS Alsterwasser was developed in Germany as a part of the Zemship (Zero Emission Ship) project [3, 20. The total project budget was $€ 5.5$ million, of which $€ 2.4$ million was co-funded by the European Union life program [21. A hydrogen fuelling station has been also built for this ship as a part of the project. This ship is used as a case study in this paper and its main specifications are shown in Table 1 .

\begin{tabular}{l|l} 
Table 1: Specifications of the FCS Alsterwasser passenger vessel \\
\hline Capacity & 100 passengers \\
Length & $25.5 \mathrm{~m}$ \\
Breadth & $5.36 \mathrm{~m}$ \\
Depth & $2.65 \mathrm{~m}$ \\
Draft & $1.33 \mathrm{~m}$ \\
Displacement & 72 tonnes \\
Top speed & $8 \mathrm{kn}$ \\
Powering & $2 \mathrm{PEMFC} \mathrm{of} 48 \mathrm{~kW}$ each \\
& $360 A h / 560 \mathrm{~V}$ lead-gel battery
\end{tabular}

This ship is equipped with two PEMFC systems and a DC-DC converter to stabilise the fuel cell voltage. The fuel cell system is hybridized with a lead-gel battery system to deliver the propulsion power to an electric motor as shown in Figure 1 without producing any harmful emissions proving to be a highly reliable power system. Twelve tanks of $50 \mathrm{~kg}$ of hydrogen are installed onboard the ship at a pressure of 350 bar which is sufficient for about three operational days without refuelling [3]. The required time of the refuelling operation is about 12 minutes [21.

The operational area of FCS Alsterwasser includes the River Elbe, inner city waterways, Hafen City and Lake Alster in Hamburg, Germany for round and charter trips [20]. 


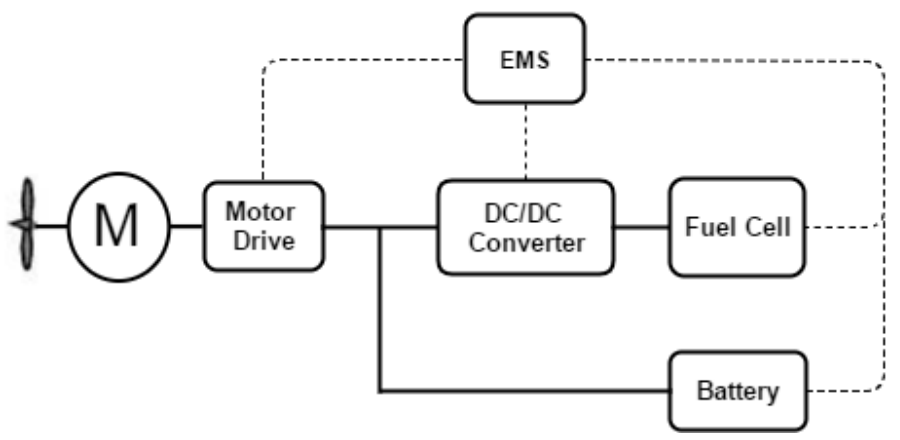

Figure 1: FCS Alsterwasser fuel cell/battery hybrid system

Therefore, its operational profile has considerable variation in power requirement as shown in Figure 2 Part of the real typical power requirement of the ship during its voyage on the Aslter, Hamburg has been measured as shown in Figure 2 and it is available in 20,10 . This power requirements includes propulsion and auxiliary power and it shows power requirements during cruising, docking, stopping, and acceleration phases of the ship journey.

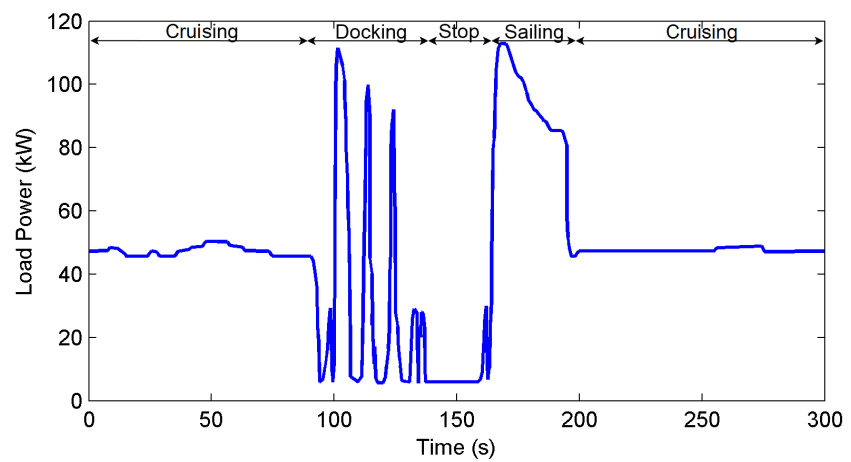

Figure 2: Typical load characteristics on the Alster

In order to have power requirements of the ship during a full voyage, an extrapolation of the power requirements shown in Figure 2 has been made considering a voyage from Finkenwerder to Landungsbrucken as displayed in Figure 3 . Then, the developed power requirements shown in Figure 3 is repeated for 8 times in order to cover the daily operation of ship.

Each leg of the examined voyage contains 4 stops between the two destinations as shown in Figure 4 and its duration is about 1 hour as detailed in Table 2 , The developed power requirements is then used as an input to the simulations as will be discussed in the following sections.

\section{Energy management strategies}

\subsection{State-based EMS}

For the same examined ship, a state-based EMS was developed in [10 to split the required power between the

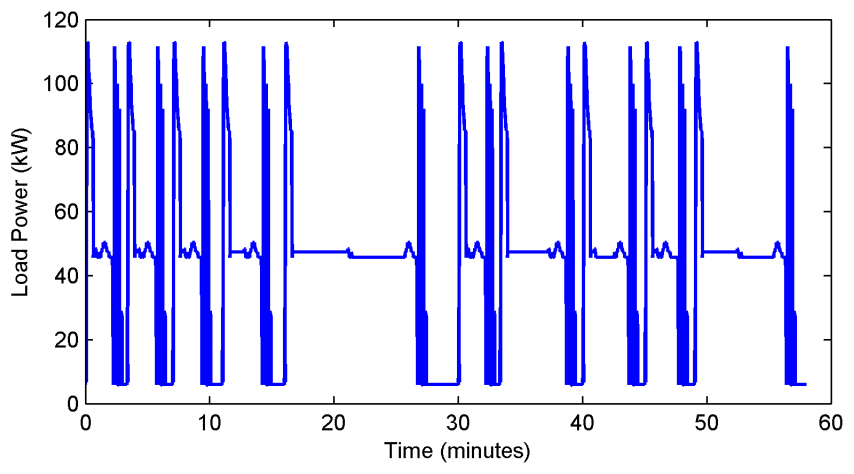

Figure 3: Developed power requirement of a real full voyage

Table 2: Finkenwerder - Landungsbrucken time table 22

\begin{tabular}{|c|c|c|c|}
\hline Landungsbrucken & 19.15 & Finkenwerder & 19.45 \\
Altona & 19.18 & Bubendey-Ufer & 19.48 \\
Dockland & 19.22 & Neumuhlen & 19.55 \\
Neumuhlen & 19.26 & Dockland & 20.00 \\
Bubendey-Ufer & 19.31 & Altona & 20.04 \\
Finkenwerder & 19.43 & Landungsbrucken & 20.13 \\
\hline
\end{tabular}

fuel cell and battery systems with an objective of maximizing the system efficiency. This control strategy is a deterministic rule-based method which can contain many operating states to control the energy flow between the components of the hybrid fuel cell power systems [23]. These operating states is based on the operational limits of the fuel cell and battery systems into consideration, the required load power, and the battery SOC.

In this strategy, the ship required load power $\left(P_{\text {load }}\right)$ is compared with different combinations of the fuel cell and battery systems operating limits which are fuel cell minimum power $\left(P_{\mathrm{FCmin}}\right)$, optimum fuel cell power $\left(P_{\mathrm{FCopt}}\right)$, maximum fuel cell power $\left(P_{\mathrm{FCmax}}\right)$, battery optimum discharge power $\left(P_{\text {optdis }}\right)$, battery optimum charge power $\left(P_{\text {optchazi }}\right)$ and battery optimum power $\left(P_{\mathrm{BATopt}}\right)$ taking into consideration the battery SOC limits as shown in Table 3

The values of the operating limits of the fuel cell and battery systems are decided based on the voltage and cur-

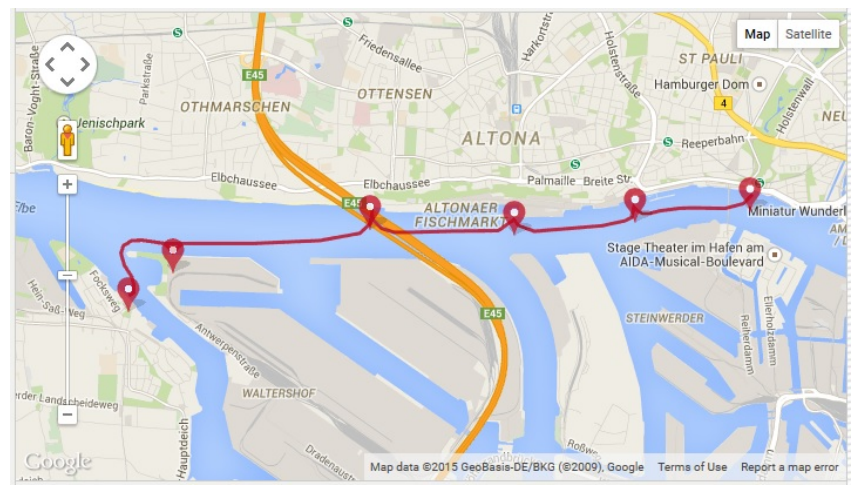

Figure 4: The examined vessel route 22 
Table 3: Summary of a state-based EMS 10

\begin{tabular}{l|c|c|c}
\hline Battery SOC & State & Load Power & Fuel cell reference power \\
\hline SOC $>80 \%$ & 1 & $P_{\text {load }} \leq P_{\mathrm{FCmin}}$ & $P_{\mathrm{FCmin}}$ \\
& 2 & $P_{\text {load }} \leq P_{\mathrm{FCmin}}+P_{\text {optdis }}$ & $P_{\mathrm{FCmin}}$ \\
& 3 & $P_{\text {load }} \leq P_{\mathrm{FCmax}}+P_{\text {optdis }}$ & $P_{\mathrm{FC}}=P_{\text {load }}-P_{\text {optdis }}$ \\
& 4 & $P_{\mathrm{FCmax}}+P_{\text {optdis }}<P_{\text {load }}$ & $P_{\mathrm{FCmax}}$ \\
\hline $50 \% \leq \mathrm{SOC} \leq 80 \%$ & 5 & $P_{\text {load }} \leq P_{\mathrm{FCmin}}$ & $P_{\mathrm{FCmin}}$ \\
& 6 & $P_{\text {load }} \leq P_{\mathrm{FCopt}}-P_{\mathrm{BATopt}}$ & $P_{\text {load }}$ \\
& 7 & $P_{\text {load }} \leq P_{\mathrm{FCopt}}+P_{\mathrm{BATopt}}$ & $P_{\mathrm{FCopt}}$ \\
& 8 & $P_{\text {load }} \leq P_{\mathrm{FCmax}}$ & $P_{\text {load }}$ \\
& 9 & $P_{\text {load }}>P_{\mathrm{FCmax}}$ & $P_{\mathrm{FCmax}}$ \\
\hline SOC $<50 \%$ & 10 & $P_{\text {load }} \leq P_{\mathrm{FCmax}}-P_{\text {optchar }}$ & $P_{\text {load }}+P_{\mathrm{optchar}}$ \\
& 11 & $P_{\text {load }}>P_{\mathrm{FCmax}}-P_{\text {optchar }}$ & $P_{\mathrm{FCmax}}$ \\
\hline
\end{tabular}

rent limits of these systems in an attempt to maximize the efficiency of the hybrid system. According to $P_{\text {load }}$ and the battery SOC, the fuel cell power is determined. Then, the battery is charged or discharged based on the difference between the fuel cell power and $P_{\text {load }}$. As illustrated in Table 3, the fuel cell system operates at its minimum power limit during low required power with normal and high battery SOC as in states 1, 2, and 5. Fuel cell system works at its maximum limit when the battery SOC is low or during high required power as in states 4, 9, and 11 . Meanwhile the fuel cell system follows the required load power as in states $3,6,8$, and 10 and it operates at its optimum power in state 7 .

\subsection{Equivalent fuel consumption minimization strategy (ECMS)}

ECMS is one of the real-time optimization approach control methods which is based on cost functions. The objective of ECMS is to minimize the instantaneous fuel consumption of the hybrid system and its concept was proposed by 24 . The hybrid system fuel consumption $(C)$ in this strategy consists of the actual fuel cell hydrogen consumption $\left(C_{\mathrm{FC}}\right)$ in addition to the equivalent consumption of the battery $\left(C_{\text {Batt }}\right)$. The optimization problem in order to minimize the equivalent hydrogen consumption can be formulated as follows:

$$
P_{\text {FCopt }}=\stackrel{\operatorname{argmin} C}{P_{\mathrm{FCopt}}}=\frac{\operatorname{argmin}\left(C_{\mathrm{FC}}+\alpha \cdot C_{\mathrm{Batt}}\right)}{P_{\mathrm{FCopt}}}
$$

where $(\alpha)$ is a penalty coefficient used to modify the equivalent fuel consumption of the battery according to the battery SOC deviation from its target and it is calculated as a function of battery SOC limits as follows:

$$
\alpha=1-2 \mu \frac{\left(\mathrm{SOC}-0.5\left(\mathrm{SOC}_{\mathrm{H}}+\mathrm{SOC}_{\mathrm{L}}\right)\right)}{\mathrm{SOC}_{\mathrm{H}}-\mathrm{SOC}_{\mathrm{L}}}
$$

where $(\mu)$ is the SOC constant used to balance the battery SOC during operation $25,\left(\mathrm{SOC}_{\mathrm{H}}\right)$ and $\left(\mathrm{SOC}_{\mathrm{L}}\right)$ are the upper and lower limit of the battery SOC respectively 26, 27. According to 1, an optimum fuel cell power is calculated as a function of the load power and battery SOC.
This optimum fuel cell power is limited between a minimum and maximum fuel cell power to avoid the operation in a poor efficiency region. The calculated fuel cell power is subtracted from the required load power to determine the battery power. Then, fuel cell power and battery power are divided by the voltage to calculate the required current from each system as shown in Figure 5 .

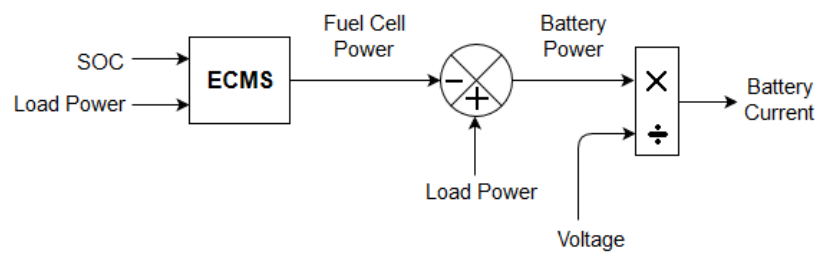

Figure 5: Equivalent fuel consumption minimization strategy scheme

\subsection{Classical PI EMS}

Due to its simplicity and ease of online tuning, EMS that based on PI controllers have been proposed for hybrid propulsion systems. The objectives of PI EMS is to maintain the battery SOC at a reference value and allow the fuel cell to provide a steady state power [11, 12]. By maintaining the battery SOC at a nominal value, its performance and lifetime can be improved. This strategy uses a PI controller to decide the battery power as a function of the battery SOC deviation form its reference value (SOC_Ref). The battery power is then removed from the required load power to obtain the fuel cell power as shown in Figure 6 .

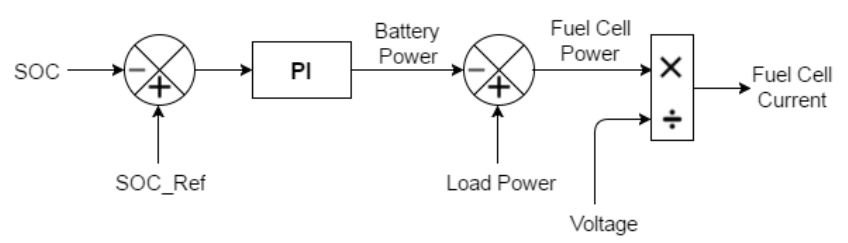

Figure 6: Classical PI control energy management strategy [1]

The main inputs to this strategy are the required load power and battery SOC. This strategy tends to use more 
power from the battery system when the battery SOC is above its reference value meanwhile the fuel cell provides low power. When the battery SOC below its reference value, the fuel cell system is used to provide the load power and charge the battery to its reference value. In order to have balance between the PI controller response time and stability, the controller parameters are tuned for the examined driving cycle using the MATLAB control system toolbox 28 .

\subsection{Charge-depleting charge-sustaining EMS}

One of the most popular strategies for hybrid systems is the CDCS strategy in which the hybrid system required power is supplied from the battery system in a chargedepleting (CD) mode until the battery SOC decreases to a certain limit while the fuel cell system is turned off or works at its minimum power 29, 30. By reaching the battery SOC limited threshold, the hybrid system is switched to a charge-sustaining (CS) mode for the rest of the journey where the fuel cell system provides the required power for the load and keeps the battery SOC constant as shown in Figure 7

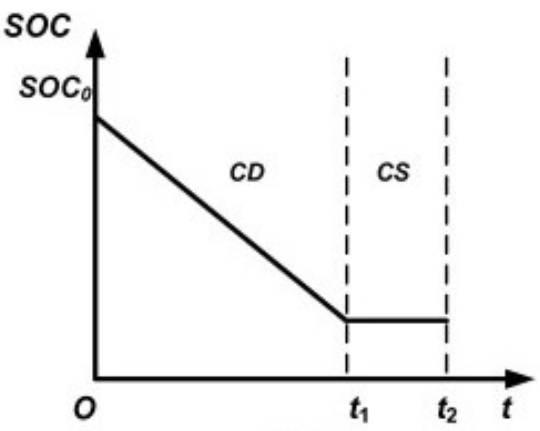

Figure 7: Charge depleting charge sustaining strategy scheme 7

CDCS strategy is often used if the trip length is not known a priori. Moreover, beside its simplicity, prioritizing battery power consumption by the CDCS EMS results in minimizing the hydrogen fuel consumption and its operational cost [30, 31].

\subsection{Multi-scheme EMS}

Because each EMS has its main objective and has different impacts on the overall efficiency, hydrogen and total energy consumption and operational cost of the hybrid system, a multi-scheme EMS should be used [11. A multi-scheme EMS that contains different strategies, then it switches between different strategies during the voyage and chooses the suitable strategy at each instant to further improve the performance of the fuel cell hybrid system. In order to increase the ship's energy efficiency, the objective of the developed multi-scheme EMS is to minimize the total consumed energy by the hybrid system. The total energy not only includes the hydrogen consumption used by the fuel cell system, but also includes the depleted energy from the battery system during the voyage and the required energy to charge the battery system back to its initial SOC. The developed multi-scheme EMS consists of the four considered strategies in this study which are: state-based EMS, ECMS, classical PI EMS, and CDCS strategy. These strategies are combined in addition to a code that switches between these strategies during the voyage to minimize the total consumed energy based on the required load power and the current battery SOC.

In order to design the multi-scheme EMS, the typical power requirements of the examined ship is divided into three modes; low power mode, cruising mode, and high power mode as shown in Figure 8. Low power mode includes the stopping phase of the ship voyage and low power requirements during the docking phase. The cruising mode contains the ship power consumption around its cruise speed while the high power mode includes the peak requirements of the ship during acceleration and docking.

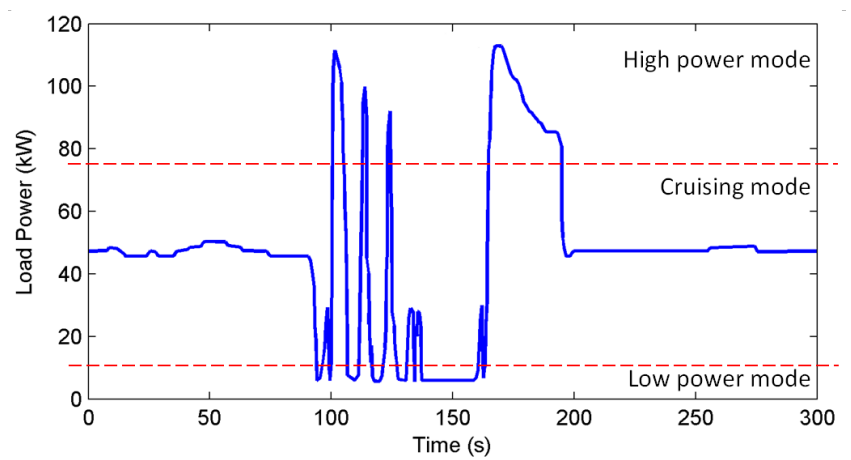

Figure 8: Different modes of the ship typical power requirements for the multi-scheme EMS

Regarding the battery SOC which affects the power split between the fuel cell and battery systems, it has been divided into low, medium, and high SOC regions. Then, the four considered strategies has been compared in terms of the total consumed energy for the three different power modes shown in Figure 8 starting with different initial battery SOC. By doing this comparison, the suitable strategy that minimizes the total consumed energy is selected at different battery SOC and different power modes for the examined voyage. Finally, a code has been developed to implement this comparison to select the the suitable strategy during the voyage based on the required load power and battery SOC as illustrated in Figure 9

In the case of starting with high initial battery SOC as for example, the multi-scheme EMS uses the classical PI EMS until the battery SOC decreases to the medium SOC region. Then, the ECMS and CDCS strategies are used instead of the classical PI as shown in Figure 9. This is because the classical PI EMS consumes more energy than the ECMS and CDCS strategies at the medium SOC region since the classical PI EMS maintains the battery SOC around a reference value of $60 \%$. Consequently, the developed code allows the hybrid system to use different strategies during the voyage according to the required load 


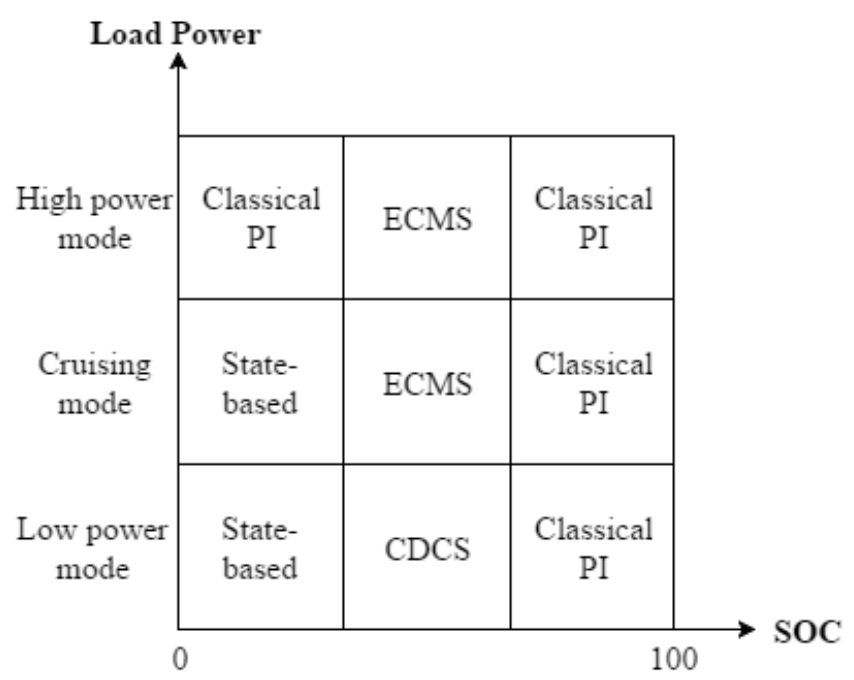

Figure 9: Developed code of the multi-scheme EMS for the examined case study power and current battery SOC in a way that reduces the total consumed energy by the end of the voyage. In the next section, the developed multi-scheme EMS as well as the state-based EMS, ECMS, classical PI EMS, and CDCS strategy are implemented in MATLAB/Simulink environment to be compared. Moreover, the examined ship's hybrid system is also implemented in Simulink environment using Simscape Power Systems (SPS) toolbox.

\section{Simulation implementation}

The hybrid fuel cell/battery system of the examined ship as well as the studied strategies are modelled mathematically and implemented in MATLAB/Simulink environment in order to study each strategy and its effect on the total consumed hydrogen, energy, operational cost, and stresses. The hybrid system simulation model consists of a Fuel cell\&DC-DC converter subsystem, Battery subsystem, Load power requirement subsystem, and an EMS subsystem as shown in Figure 10. In this section, the modelling approach of each subsystem is described.

\subsection{Fuel cell \&3 DC-DC converter subsystem \\ 4.1.1. Fuel cell}

A considerable number of PEMFC performance mathematical models have been developed due to its advantages and potential applications which includes portable, stationary, and transportation applications. A generic model of PEMFC has been developed and implemented in Simulink as shown in Figure 11.

This model has been validated against experimental data and real datasheet performance in 32 with an error within $\pm 1 \%$. This model combines the features of PEMFC electrical and chemical models and it can represent the PEMFC steady-state performance as well as its dynamic performance taking into consideration fuel cell

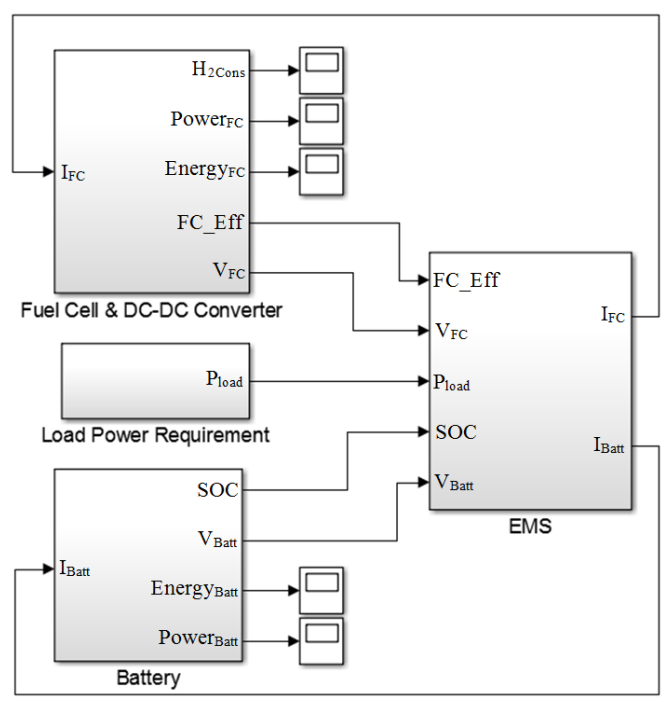

Figure 10: Hybrid fuel cell/battery power system in Simulink/MATLAB environment

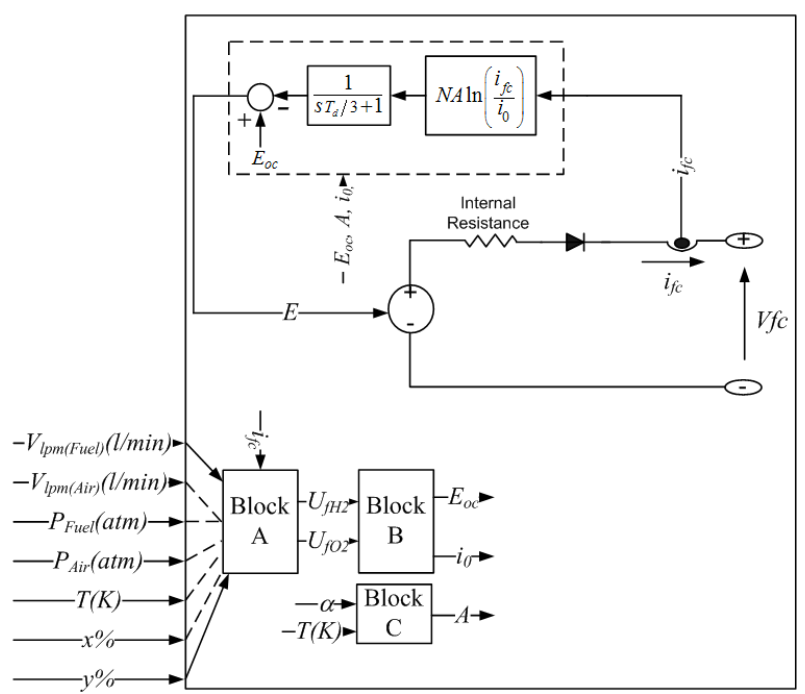

Figure 11: Fuel cell model in Simulink/MATLAB environment adapted from 32 
response time. This model is integrated in the SPS toolbox in the Simulink library of electric drives. The required information to define this model can be obtained from the fuel cell polarization curve or from the its datasheet which makes this model easy to use.

For this study, a preset validated Simulink PEMFC model of $50 \mathrm{~kW}$ nominal power and $120 \mathrm{~kW}$ maximum power is used assuming that it is fed with hydrogen and a constant resistance of $0.664 \Omega$. Figure 12 shows the fuel cell model characteristics. The nominal efficiency of the used PEMFC model is $55 \%$ as shown in Figure 13 . The consumed energy by the fuel cell subsystem is calculated as follows

$$
\text { Energy }_{\mathrm{FC}}=\mathrm{H}_{2 \mathrm{Cons}} \times \mathrm{HHV}_{\mathrm{H}_{2}}
$$

where $\left(\mathrm{HHV}_{\mathrm{H}_{2}}\right)$ is the hydrogen higher heating value and $\left(\mathrm{H}_{2 \mathrm{Cons}}\right)$ is the PEMFC hydrogen consumption which is calculated as follows

$$
\mathrm{H}_{2 \text { Cons }}=\frac{\mathrm{N}}{\mathrm{F}} \int \mathrm{I}_{\mathrm{FCnet}} . d t
$$

where $(\mathrm{N})$ is the number of cells, $(\mathrm{F})$ is the Faraday constant and $\left(\mathrm{I}_{\mathrm{FCnet}}\right)$ is the net current drained from the PEMFC.

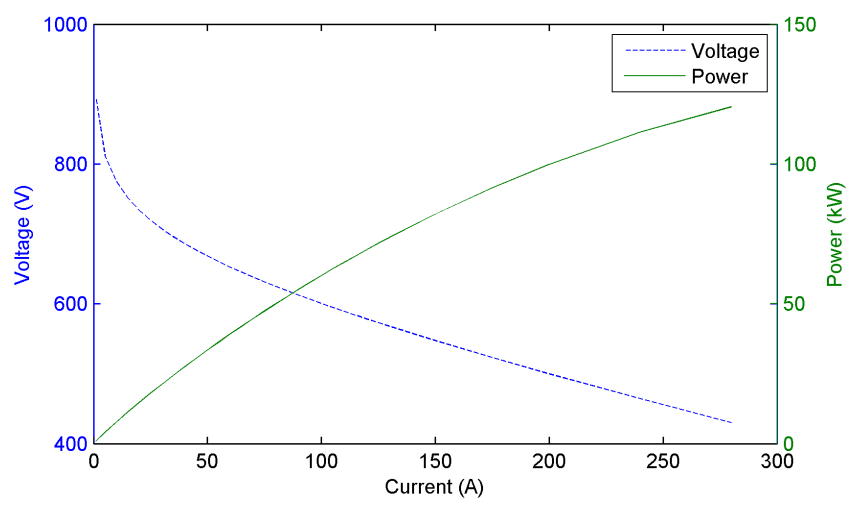

Figure 12: Fuel cell voltage and power versus current

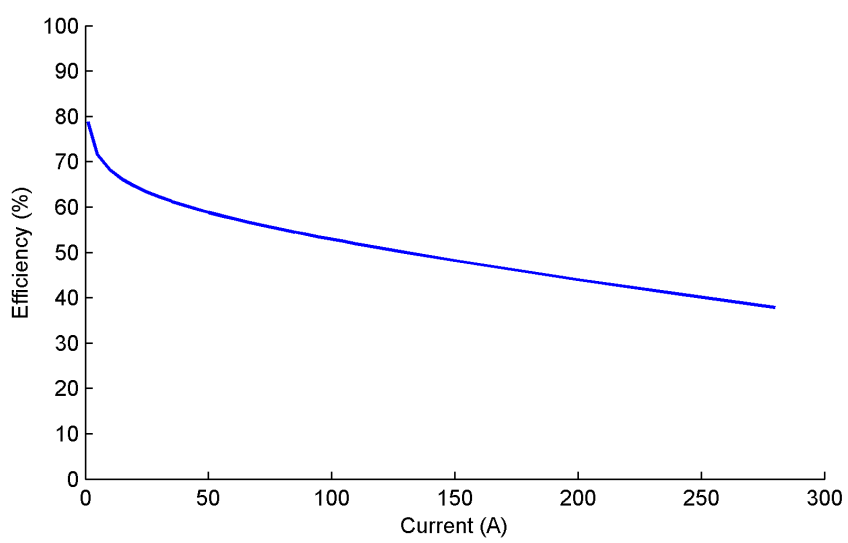

Figure 13: Fuel cell efficiency versus current

\subsection{2. $D C-D C$ converter}

A boost type unidirectional DC-DC converter is used to connect the PEMFC to the DC bus as shown in Figure 1 in order to regulate its output power and voltage. The operating voltage ratio $(\mathrm{k})$ of the DC-DC converter is used to readjust the net current supplied by the PEMFC into the DC bus as follows 33

$$
\begin{aligned}
& \mathrm{k}=\mathrm{V}_{\mathrm{Batt}} / \mathrm{V}_{\mathrm{FC}} \\
& \mathrm{I}_{\mathrm{FCnet}}=\mathrm{I}_{\mathrm{FC}} \times \mathrm{k} \times \eta_{\text {Con } v}
\end{aligned}
$$

where $\left(\mathrm{V}_{\mathrm{Batt}}\right)$ is the battery voltage, $\left(\mathrm{V}_{\mathrm{FC}}\right)$ is the fuel cell voltage and $\left(\mathrm{I}_{\mathrm{FC}}\right)$ is the required current from the fuel cell/DC-DC converter subsystem assuming a constant efficiency of the converter $\left(\eta_{C o n v}\right)$ to be $95 \%$ [34. As shown in Figure 14, the used converter is composed of a switch $\mathrm{S}$, an inductor $\mathrm{L}$, and a diode $\mathrm{D}$.

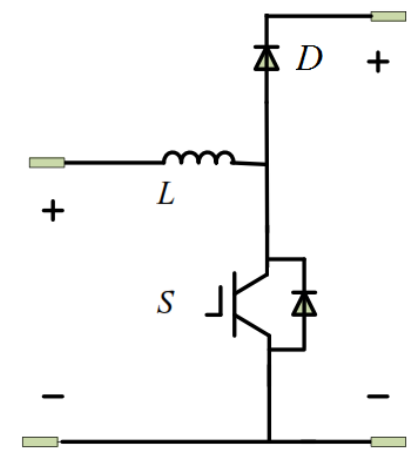

Figure 14: Boost DC-DC converter electrical scheme 10

\subsection{Battery subsystem}

For transportation applications, batteries are usually used as an energy storage device. The examined ship is equipped with a lead-gel battery with a capacity of $360 \mathrm{Ah}$ and a voltage of $560 \mathrm{~V}$. For this study, an improved easyto-use battery model has been developed and validated in 35 is used. This model can represent the steady state battery behaviour as well as its dynamic behaviour taking into consideration the battery response time assuming a constant internal resistance of $0.0156 \Omega$. Figure 15 plots the battery voltage versus its SOC. Moreover, this model is integrated in the SPS toolbox and Figure 16 shows its implementation in Simulink.

The consumed energy from the battery subsystem (Energy Batt $_{\text {) }}$ is calculated as a function of its power ( power $_{\text {Batt }}$ ) as follows

$$
\text { Energy }_{\text {Batt }}=\int \text { power }_{\text {Batt }} . d t
$$

The battery power is calculated as a function of its voltage and current $\left(\mathrm{I}_{\text {Batt }}\right)$ as follows

$$
\text { power }_{\text {Batt }}=\mathrm{V}_{\text {Batt }} \times \mathrm{I}_{\text {Batt }}
$$




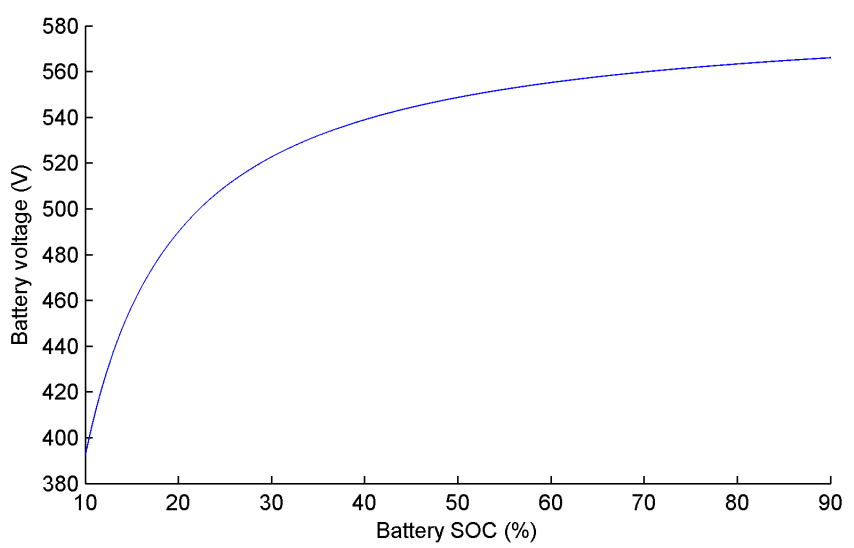

Figure 15: Battery voltage versus SOC

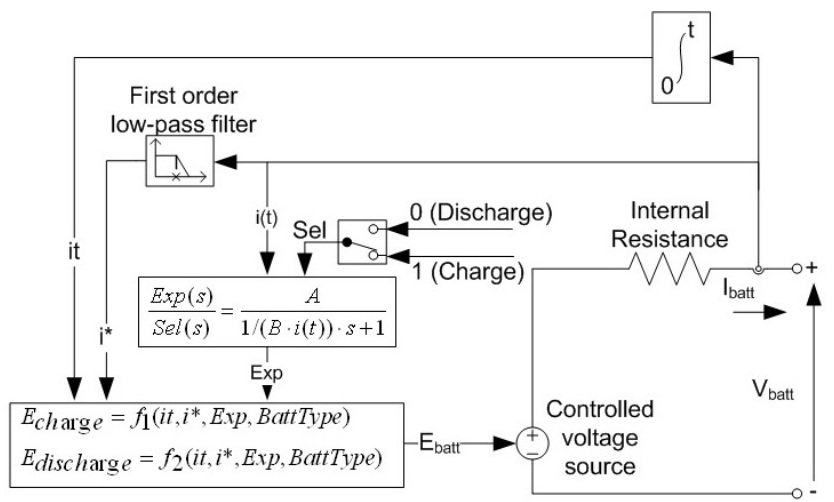

Figure 16: Battery model in Simulink/MATLAB environment adapted from 36.
The energy required to recharge the battery back to its initial SOC $\left(\mathrm{SOC}_{\text {ini }}\right)$ is calculated as a function of the final battery $\mathrm{SOC}\left(\mathrm{SOC}_{\mathrm{fin}}\right)$ and its capacity $(Q)$ as follows

$$
\text { Energy }_{\text {Batt }_{\mathrm{Ch}}}=\frac{\left(\mathrm{SOC}_{\mathrm{ini}}-\mathrm{SOC}_{\mathrm{fin}}\right) \times Q \times \mathrm{V}_{\mathrm{Batt}}}{\text { Charging efficiency }}
$$

\subsection{EMS subsystem}

The four examined EMS as well as the developed multischeme EMS are modelled and implemented in Simulink environment in order to be compared in terms of hydrogen consumption, total consumed energy and operational cost and stresses on the power sources of the hybrid propulsion system considering a developed full driving cycle of 8 hours that based on the real typical load requirements of the examined ship shown in Figure 2. The total energy includes the fuel cell consumed energy from (3), battery depleted energy from (6), and the used energy to recharge the battery back to its initial battery SOC (Energy Batt $_{\mathrm{Ch}}$ ) assuming a charging efficiency of $88 \%$ [37] as follows

$$
\text { Energy }_{\text {Total }}=\text { Energy }_{\mathrm{FC}}+\text { Energy }_{\mathrm{Batt}}+\text { Energy }_{\mathrm{Batt}} \mathrm{Ch}
$$

The main inputs of the EMS subsystem are the required load power, fuel cell voltage and efficiency, and battery SOC and voltage. Based on these inputs, the used EMS converts the required load power into current and splits it between the fuel cell and battery subsystems as shown in Figure 10. The EMS subsystem using the statebased EMS is validated against the published results in [10] for the same examined ship considering the typical load requirements shown in Figure 2. By implementing the hybrid fuel cell/battery system in Simulink as described earlier and using the same initial battery SOC of $65 \%$ as suggested in [10, the state-based EMS is validated as shown in Figures 17 to 19 .

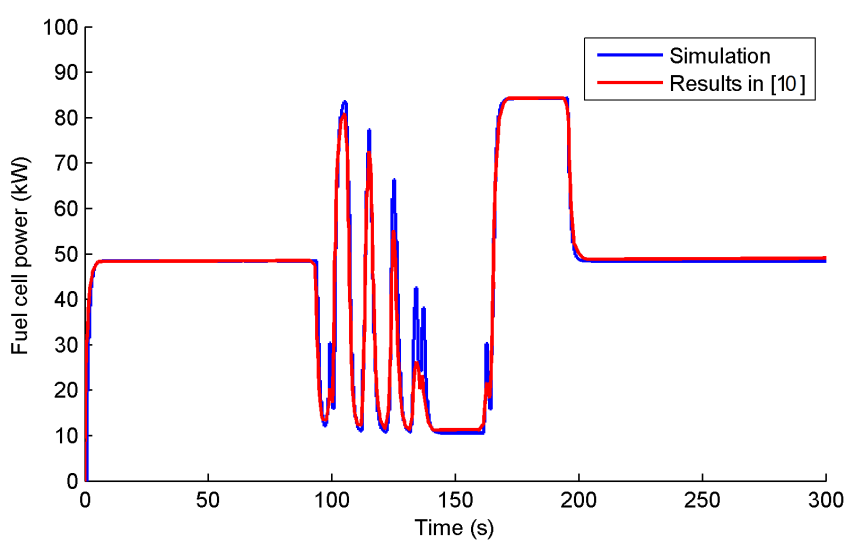

Figure 17: Validation of fuel cell power

As shown in Figures 17 to 19 , there is a good agreement between the simulation results and the published results in [10] for the state-based EMS. In the following section, the 


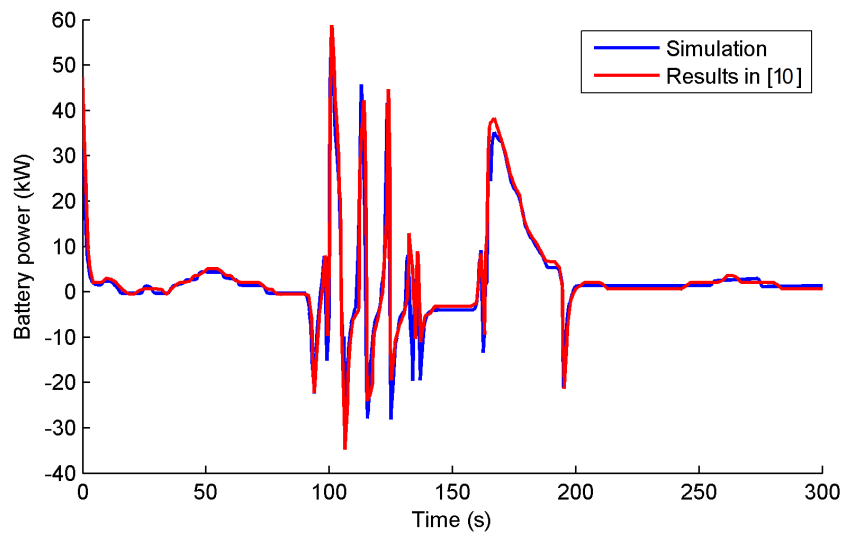

Figure 18: Validation of battery power

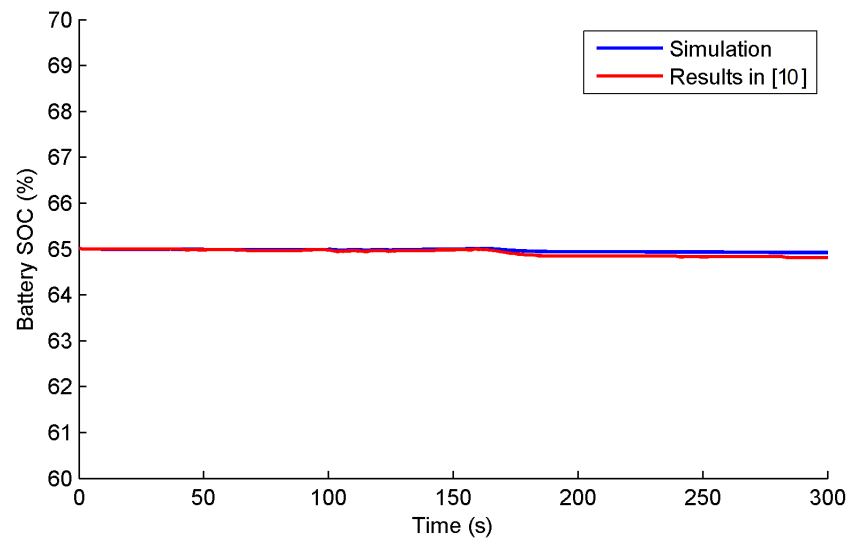

Figure 19: Validation of battery SOC

simulation results of the four studied EMS as well as the developed multi-scheme EMS are compared in terms of hydrogen consumption and total consumed energy, total cost, and stresses considering a daily driving cycle of 8 hours of the examined ship.

\subsection{Simulation parameters}

In order to compare different EMS appropriately, the same fuel cell and battery models are used with the same initial conditions and operating limits. To avoid operating at poor efficiency region, fuel cell minimum power is $5 \mathrm{~kW}$ and its maximum power is $80 \mathrm{~kW}$ as suggested in [10] while its optimum power value is $50 \mathrm{~kW}$ the same as the nominal power of the used PEMFC model. Regarding the battery, a SOC of $65 \%$ is chosen as an initial condition for different strategies. For the classical PI EMS, a reference value of the battery SOC of $60 \%$ is selected as recommended by automotive industry designers [12. For the ECMS, $\mathrm{SOC}_{\mathrm{H}}$ and $\mathrm{SOC}_{\mathrm{L}}$ are set to $80 \%$ and $30 \% 38$ and the SOC constant $\mu$ is set to be 0.6 as reported in [11, 27, 25. Meanwhile, the battery threshold value for the CDCS EMS is $30 \%$ [30. The battery C-rate limits are $0.3 \mathrm{C}$ and $2 \mathrm{C}$ as recommended by the battery manufacturer 10 .

\section{Results \& discussion}

Considering a daily driving cycle of the ship of 8 hours, simulation results show that the developed multi-scheme EMS has less energy consumption than the state-based, ECMS, CDCS, and the classical PI strategies by $1.4 \%$, $3.9 \%, 2.8 \%$, and $0.8 \%$ respectively as shown in Figure 20 . This indicates that changing the used EMS during the voyage can be better than using a single EMS and result in an energy saving. The total consumed energy shown in Figure 20 includes fuel cell and battery used energy during the voyage as well as the required energy to charge the battery back to its initial SOC.

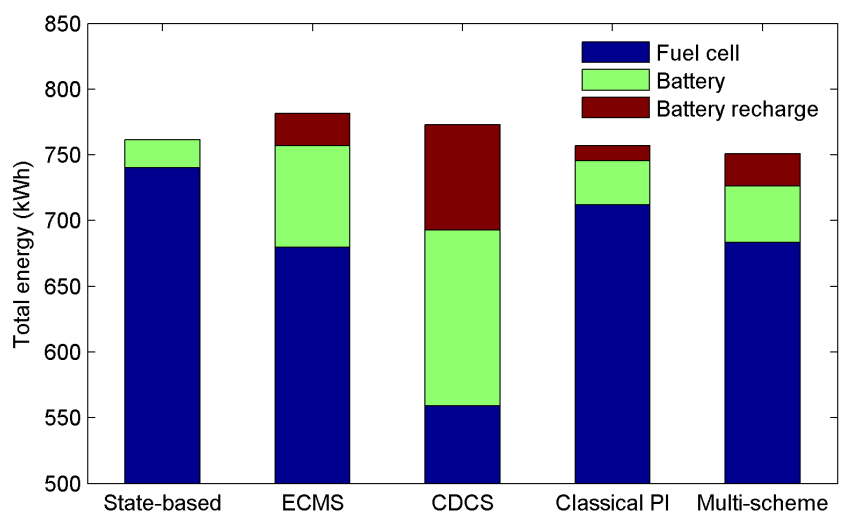

Figure 20: Total consumed energy comparison

Regarding the total cost, the multi-scheme EMS has approximately the same operational cost as other strategies as shown in Figure 21. The multi-scheme EMS results in a cost saving of $0.7 \%$ and $0.02 \%$ compared to the CDCS and state-based strategies respectively. However, the total cost of the multi-scheme EMS is slightly higher than the ECMS and classical PI strategies by $0.5 \%$ and $0.2 \%$ respectively. This cost includes the hydrogen cost and the battery recharging cost assuming a wind generated hydrogen cost of $4.823 \$ / k g[39$ and an average electricity price of $0.284 \$ / k W h$ for the battery recharging using shoreshared (or shore-side) energy [40].

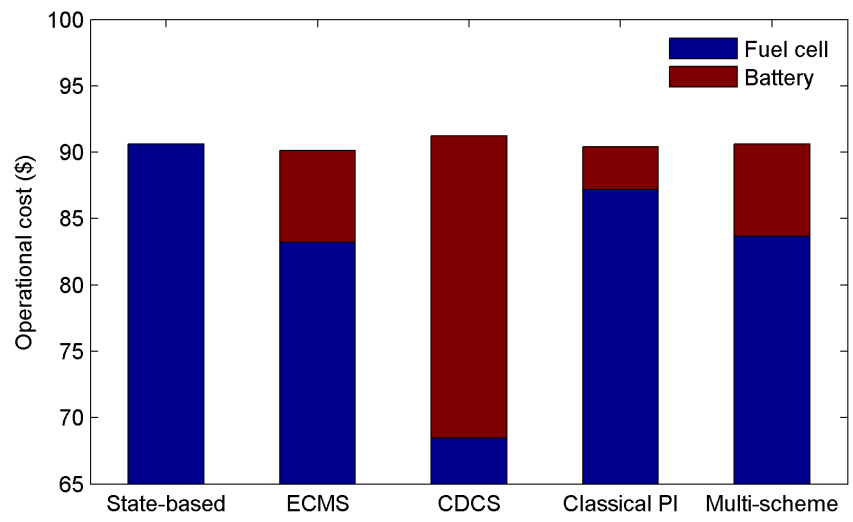

Figure 21: Total cost comparison 
Figure 22 plots the ship hydrogen consumption using different EMS for the examined 8 hours driving cycle. It can be noted that the CDCS EMS has the lowest fuel consumption as expected since it prioritizes the usage of battery energy as shown in Figure 23. The developed multischeme EMS has lower hydrogen consumption than the state-based and classical PI EMS by $7.7 \%$ and $4 \%$ respectively. However, it has higher hydrogen consumption than the ECMS and CDCS EMS by $0.6 \%$ and $22.2 \%$ respectively.

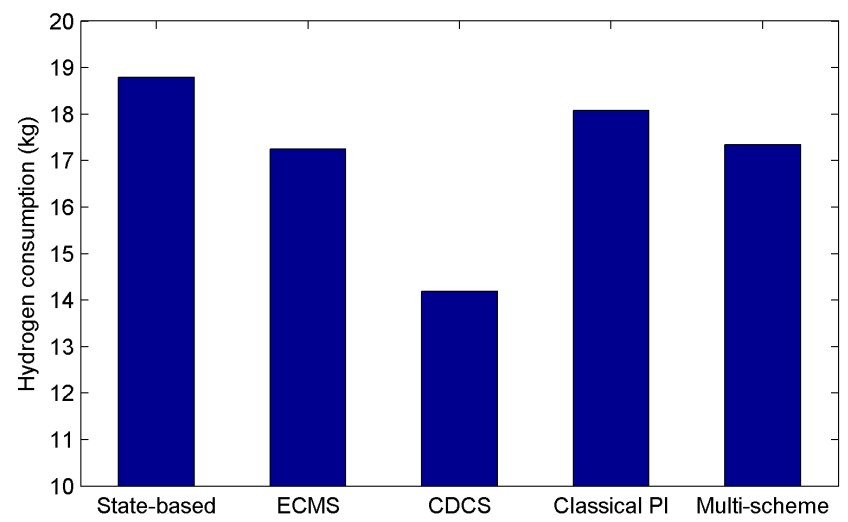

Figure 22: Hydrogen consumption comparison

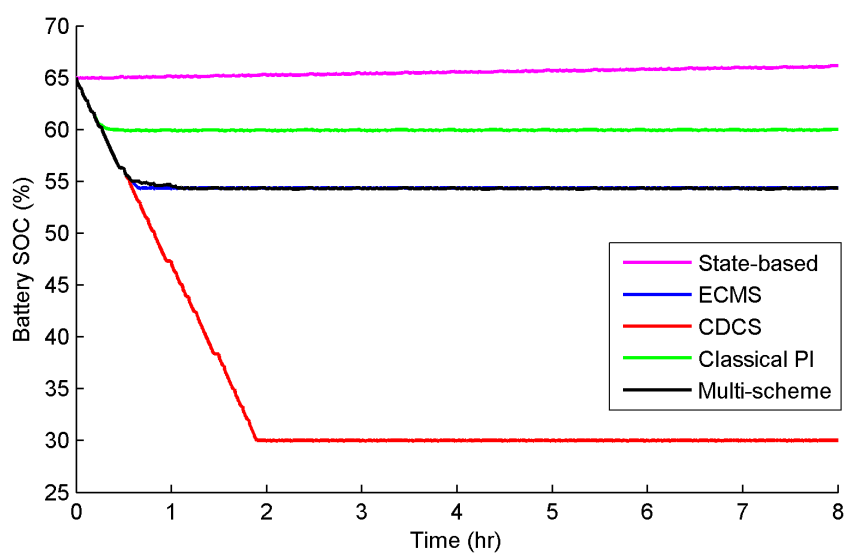

Figure 23: Battery SOC during the examined voyage for different strategies

As shown in Figure 23, at an initial battery SOC of

$65 \%$, the developed multi-scheme EMS discharges the battery energy in a similar way to the ECMS which makes the hydrogen consumption of both of them very close as reported by Figure 22. The classical PI and CDCS strategies tend to discharge the battery energy until it reaches its reference value at $60 \%$ and $30 \%$ respectively. Meanwhile, the state-based strategy regulates the fuel cell to provide most of the power since the battery SOC is not high to be discharged therefore it has higher hydrogen consumption as shown in 22 .

\subsection{Stress analysis}

An analysis of the stresses seen by each power source is performed to investigate the effect of changing the used energy management strategy during the voyage by the multi-scheme strategy on the fuel cell and battery systems. These stresses affect the propulsion system's durability, maintenance, and lifetime. The instantaneous power from the fuel cell and battery systems during the voyage are decomposed into low frequency and high frequency components using Haar wavelet transform as suggested in 11. Then, the standard deviation of the high frequency component is calculated to have a good indication of the stresses on the fuel cell and battery for the examined voyage. As can be found in Table 4, changing the used EMS during the voyage by the proposed multi-scheme EMS doesn't increase the stresses on the hybrid fuel cell/battery system. Moreover, the fuel cell and battery stresses are lower using the multi-scheme EMS than the ECMS and CDCS strategies but at the cost of more hydrogen consumption.

\subsection{Sensitivity analysis}

\subsubsection{Impact of different initial battery SOC}

The reported saving percentages of the developed multi-scheme EMS in terms of total consumed energy, cost and hydrogen consumption can be affected by the initial conditions of the battery SOC. Therefore, different battery initial SOC have been used for the same examined voyage to study the impact of this parameter on the resulted saving percentages of the developed multischeme EMS. As detailed in Figure 24, the developed multi-scheme EMS has lower energy consumption than the four examined EMS at different initial battery SOC. The maximum energy saving percentage is $8 \%$ compared to the classical PI EMS at an initial battery SOC of $50 \%$ while the minimum energy saving percentage is $0.3 \%$ compared to the state-based EMS at an initial battery SOC of $50 \%$.

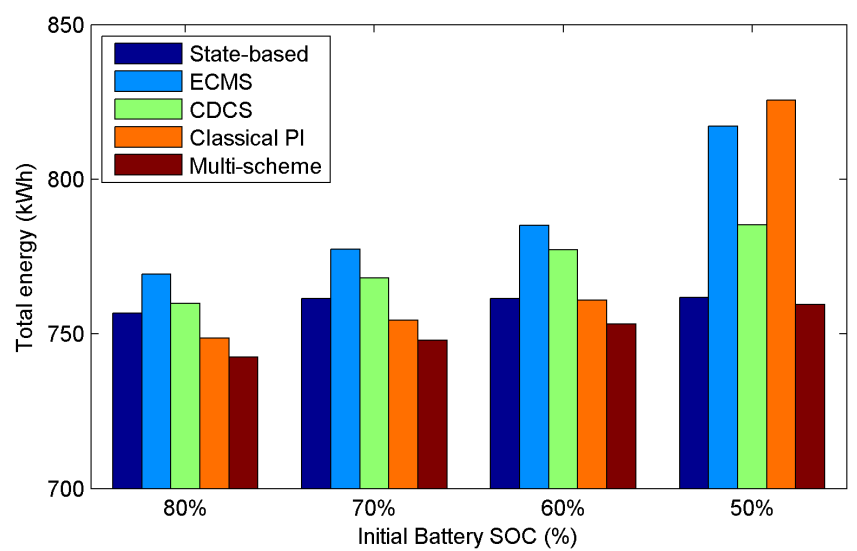

Figure 24: Impact of different initial battery SOC on total energy saving percentage of the developed multi-scheme EMS compared to other EMS

Regarding the operational cost saving percentage, the developed multi-scheme EMS can result in a saving of 7.9\% 
Table 4: Overall performance comparison of different energy management strategies for the examined voyage at an initial battery SOC of $65 \%$

\begin{tabular}{|l|c|c|c|c|c|}
\hline & State-based & ECMS & CDCS & Classical PI & Multi-scheme \\
\hline Fuel cell stress & 29.26 & 37.92 & 42.37 & 31.69 & 32.03 \\
\hline Battery stress & 15.85 & 29.92 & 40.61 & 19.18 & 22.49 \\
\hline Hydrogen consumption $(\mathrm{kg})$ & 18.79 & 17.25 & 14.19 & 18.07 & 17.35 \\
\hline Battery SOC (\%) & $65-66.11$ & $65-54.35$ & $65-30$ & $65-59.99$ & $65-54.33$ \\
\hline
\end{tabular}

compared to the classical PI EMS starting with an initial battery SOC of $50 \%$. However, the developed multischeme EMS can have higher operational cost than the state-based EMS by $1.9 \%$ starting with an initial battery SOC of $80 \%$. In case of starting with normal initial battery SOC between $60 \%$ and $70 \%$, the difference between the developed multi-scheme EMS and other strategies in terms of operational cost is less than $1 \%$ as shown in Figure 25

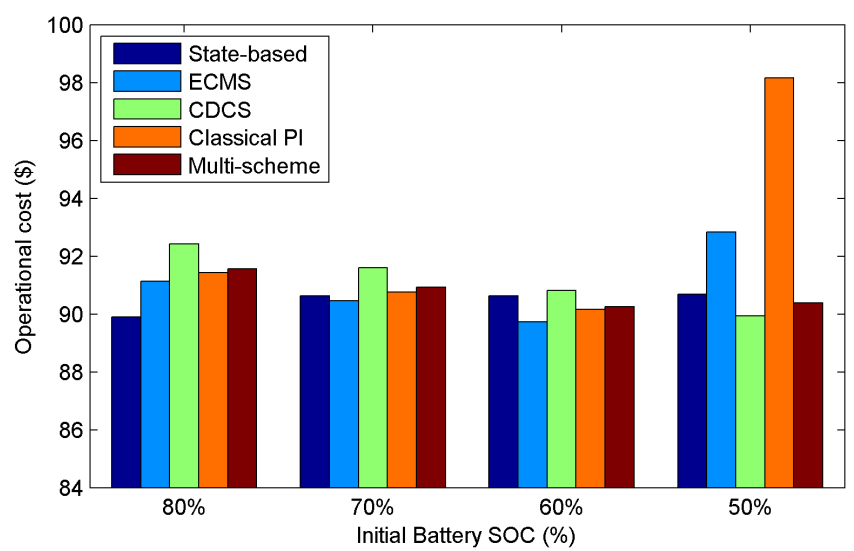

Figure 25: Impact of different initial battery SOC on total cost saving percentage of the developed multi-scheme EMS compared to other EMS

As can be seen from Figure 26. CDCS EMS has the lowest hydrogen consumption at different initial battery SOC due to the fact that CDCS supplies the required load power from the battery system whenever possible. Therefore, the maximum difference between the CDCS EMS and the developed multi-scheme EMS in terms of hydrogen consumption occurs at a high initial battery SOC of $80 \%$. Comparing with other strategies, the developed multi-scheme EMS has lower hydrogen consumption than the state-based and classical PI strategies at different initial battery SOC with a maximum hydrogen consumption saving percentages of $16.7 \%$ compared to the state-based EMS at an initial battery SOC of $80 \%$ and $7.9 \%$ compared to the classical PI EMS at an initial battery SOC of $50 \%$. Moreover, the developed multi-scheme EMS has lower hydrogen consumption by $2.6 \%$ compared to the ECMS at an initial battery SOC of $50 \%$ meanwhile it has approximately the same hydrogen consumption of the ECMS at other initial battery SOC.

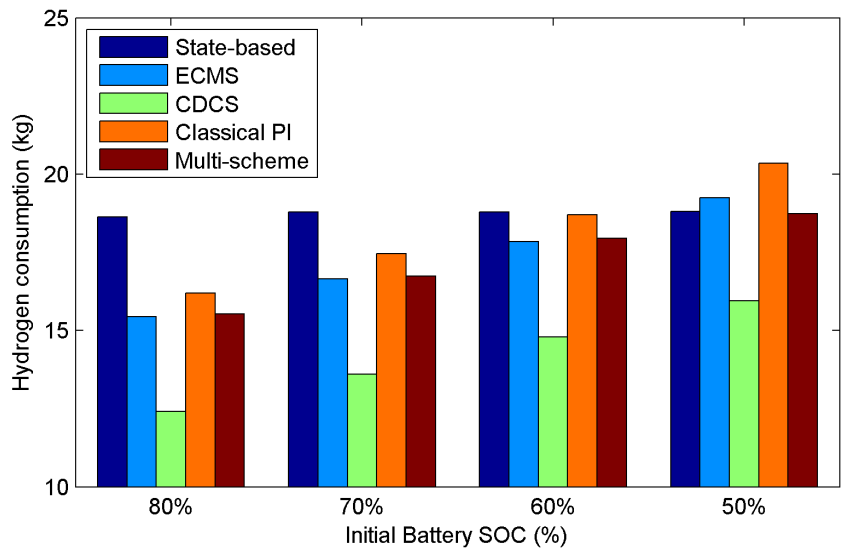

Figure 26: Impact of different initial battery SOC on hydrogen consumption saving percentage of the developed multi-scheme EMS compared to other EMS

\subsubsection{Impact of varying energy prices}

The prices of hydrogen and electricity vary spatially and temporally depending on the used production method. In order to study the impact of varying energy prices on the total cost saving percentages of the developed multischeme EMS compared to other EMS, an energy price ratio $(\beta)$ is used and it can be calculated as follows

$$
\beta=\frac{\text { Price of Hydrogen per } \mathrm{kWh}}{\text { Price of Electricity per } \mathrm{kWh}}
$$

The total cost saving percentages reported to this point corresponds to an energy price ratio of $\beta=0.43$ assuming hydrogen cost of $4.823 \$ / \mathrm{kg}$ with an energy content of $39.4 \mathrm{kWh} / \mathrm{kg}$ and electricity price of $0.284 \$ / \mathrm{kWh}$. At an initial battery SOC of $65 \%$, different values of $\beta$ are used to show how this parameter affects the total cost saving percentage as can be found in figure 27.

The results shown in Figure 27 are associated with two factors; the hydrogen consumption saving of the multischeme EMS compared to other strategies and the percentages of the hydrogen and battery recharging costs from the total operational cost. Since the developed multi-scheme and ECMS strategies have approximately the same hydrogen consumption, the cost saving percentage of the developed multi-scheme EMS compared to the ECMS is levelled off at different $\beta$ values. Also, the cost saving percentage of the developed multi-scheme EMS is more significant over the CDCS EMS at lower $\beta$ values because of the high battery recharging cost of the CDCS com- 


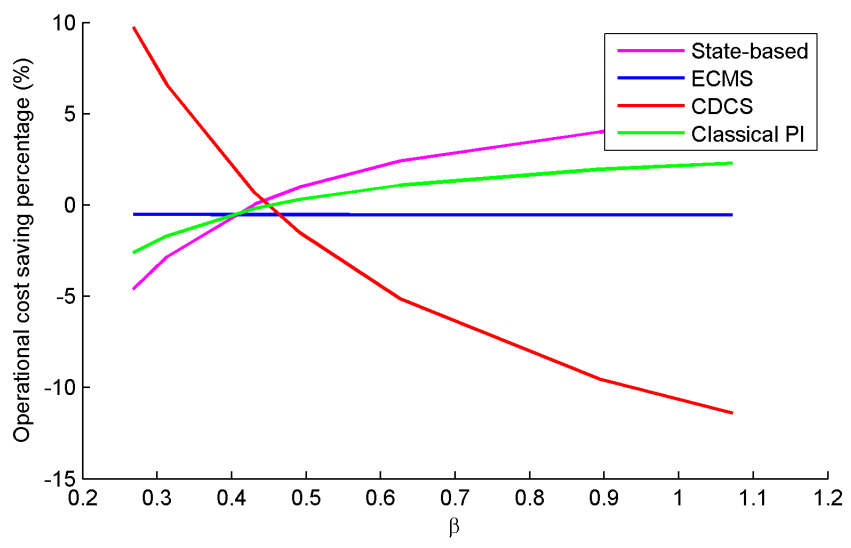

Figure 27: Impact of energy price ratio on total cost saving percentage of the developed multi-scheme EMS compared to other EMS at initial battery SOC of $65 \%$

pared to other strategies. However, at higher $\beta$ values which means higher hydrogen prices, the total cost becomes dominated by the hydrogen cost. Consequently, the total cost saving percentage over CDCS strategy gradually drops at higher $\beta$ values since CDCS has the lowest hydrogen consumption. Compared to the state-based and classical PI strategies, the developed multi-scheme EMS has higher operational cost at low $\beta$ values. At higher $\beta$ values, the operational cost saving percentage of the developed multi-scheme EMS over the state-based and classical PI strategies becomes higher due to the hydrogen consumption saving achieved by the developed multi-scheme EMS over the state-based and classical PI strategies.

\section{Conclusions}

The recent growth in popularity of hybrid fuel cell propulsion systems for transportation applications is due to its advantages of quite operation, low emissions and high efficiency. The dynamic behaviour of these systems depends remarkably on the strategy used to split the required power between different components of the hybrid system. Different energy management strategies have been reported in the literature for hybrid fuel cell propulsion systems with different objectives and advantages. Therefore, the development of a multi-scheme energy management strategy that contains different strategies and chooses the suitable EMS during the voyage based on a specific criterion is necessary.

A performance comparison of four different energy management strategies in terms of total consumed energy, hydrogen consumption, total cost, and the stresses seen by the fuel cell and battery systems has been presented for the world's first fuel cell passenger ship FCS Alsterwasser in this paper. Then, a novel multi-scheme EMS has been developed using the examined four strategies with an objective of minimizing the energy consumption that takes the required energy to recharge the battery back to its initial SOC into consideration in addition to the fuel cell and battery depleted energy during the examined voyage. The developed multi-scheme EMS has been well compared with other strategies considering a full driving cycle of 8 hours. Simulation results show that the developed multischeme EMS is more efficient at different initial battery SOC with a maximum energy saving percentage of $8 \%$. Regarding the hydrogen consumption, CDCS strategy has the lowest consumption at all initial battery SOC since it prioritizes the usage of the battery energy. However, the developed multi-scheme EMS can result in a hydrogen consumption saving over the state-based and the classical PI strategies at different initial battery SOC with a maximum saving percentage of $16.7 \%$. Furthermore, using the developed multi-scheme EMS results in approximately the same operational costs as other strategies. A sensitivity analysis shows that at higher hydrogen prices, cost saving percentages of the developed multi-scheme EMS becomes higher compared to the state-based and the classical PI strategies. Moreover, the stress analysis reveals that switching between different strategies during the voyage using the proposed multi-scheme EMS doesn't increase the operational stresses on the fuel cell and battery systems.

\section{Acknowledgement}

This research is funded by the Egyptian Government.

\section{References}

[1] E. K. Dedes, D. A. Hudson, S. R. Turnock, Assessing the potential of hybrid energy technology to reduce exhaust emissions from global shipping, Energy Policy 40 (2012) 204-218.

[2] Z. Bazari, T. Longva, Assessment of IMO mandated energy efficiency measures for international shipping, International Maritime Organization (2011).

[3] C. H. Choi, S. Yu, I.-S. Han, B.-K. Kho, D.-G. Kang, H. Y. Lee, M.-S. Seo, J.-W. Kong, G. Kim, J.-W. Ahn, S.-K. Park, D.-W. Jang, J. H. Lee, M. Kim, Development and demonstration of PEM fuel-cell-battery hybrid system for propulsion of tourist boat, International Journal of Hydrogen Energy 41 (2016) 3591 -3599 .

[4] J. T. Pukrushpan, A. G. Stefanopoulou, H. Peng, Control of fuel cell breathing, Control Systems, IEEE 24 (2004) 30-46.

[5] Y. Wang, K. S. Chen, J. Mishler, S. C. Cho, X. C. Adroher, A review of polymer electrolyte membrane fuel cells: technology, applications, and needs on fundamental research, Applied Energy 88 (2011) 981-1007.

[6] P. Melo, J. Ribau, C. Silva, Urban bus fleet conversion to hybrid fuel cell optimal powertrains, Procedia - Social and Behavioral Sciences 111 (2014) $692-701$

[7] L. Xu, M. Ouyang, J. Li, F. Yang, L. Lu, J. Hua, Optimal sizing of plug-in fuel cell electric vehicles using models of vehicle performance and system cost, Applied Energy 103 (2013) 477487.

[8] I. Valero, S. Bacha, E. Rulliere, Comparison of energy management controls for fuel cell applications, Journal of Power Sources 156 (2006) 50-56.

[9] M. Ouyang, L. Xu, J. Li, L. Lu, D. Gao, Q. Xie, Performance comparison of two fuel cell hybrid buses with different powertrain and energy management strategies, Journal of Power Sources 163 (2006) 467-479.

[10] J. Han, J.-F. Charpentier, T. Tang, An energy management system of a fuel cell/battery hybrid boat, Energies 7 (2014) $2799-2820$. 
11] S. N. Motapon, L. Dessaint, K. Al-Haddad, et al., A comparative study of energy management schemes for a fuel-cell hybrid emergency power system of more-electric aircraft, IEEE Transactions on Industrial Electronics 61 (2014) 1320-1334.

[12] A. Fadel, B. Zhou, Power management methodologies for fuel cell-battery hybrid vehicles, Technical Report, SAE Technical Paper, 2010.

[13] P. Thounthong, S. Ral, B. Davat, Energy management of fuel cell/battery/supercapacitor hybrid power source for vehicle applications, Journal of Power Sources 193 (2009) 376 - 385.

[14] L. Xu, M. Ouyang, J. Li, F. Yang, L. Lu, J. Hua, Application of pontryagin's minimal principle to the energy management strategy of plugin fuel cell electric vehicles, International Journal of Hydrogen Energy 38 (2013) 10104 - 10115.

[15] Q. Cai, D. Brett, D. Browning, N. Brandon, A sizing-design methodology for hybrid fuel cell power systems and its application to an unmanned underwater vehicle, Journal of Power Sources 195 (2010) 6559-6569.

[16] N.-C. Shih, B.-J. Weng, J.-Y. Lee, Y.-C. Hsiao, Development of a $20 \mathrm{kw}$ generic hybrid fuel cell power system for small ships and underwater vehicles, International Journal of Hydrogen Energy 39 (2014) 13894-13901.

[17] A. M. Bassam, A. B. Phillips, S. R. Turnock, P. A. Wilson, An improved energy management strategy for a hybrid fuel cell/battery passenger vessel, International Journal of Hydrogen Energy (2016). http://dx.doi.org/10.1016/j.ijhydene. 2016.08 .049

[18] L. Zhu, J. Han, D. Peng, T. Wang, T. Tang, J.-F. Charpentier, Fuzzy logic based energy management strategy for a fuel cell/battery/ultra-capacitor hybrid ship, in: International Conference on Green Energy, IEEE, 2014, pp. 107-112.

[19] Sps, http://uk.mathworks.com/products/simpower/ 2016. Accessed: 2016-04-22.

[20] C. Thimm, Zemships - the first fuel cell passenger ship in Hamburg, in: ZERO REGIO Workshop, Montecatini Terme, Italy, 2007.

[21] J. J. de Troya, C. lvarez, C. Fernndez-Garrido, L. Carral, Analysing the possibilities of using fuel cells in ships, International Journal of Hydrogen Energy 41 (2016) 2853 - 2866.

[22] HADAG, http://www.hadag.de/english/harbour-ferries. html 2015. Accessed: 2015-04-24.

[23] S. F. Tie, C. W. Tan, A review of energy sources and energy management system in electric vehicles, Renewable and Sustainable Energy Reviews 20 (2013) 82 - 102.

[24] G. Paganelli, S. Delprat, T.-M. Guerra, J. Rimaux, J.-J. Santin, Equivalent consumption minimization strategy for parallel hybrid powertrains, in: Vehicular Technology Conference, 2002. VTC Spring 2002. IEEE 55th, volume 4, IEEE, 2002, pp. 20762081.

[25] L. Xu, J. Li, J. Hua, X. Li, M. Ouyang, Adaptive supervisory control strategy of a fuel cell/battery-powered city bus, Journal of Power Sources 194 (2009) 360-368.

[26] P. Garcia, J. Torreglosa, L. Fernndez, F. Jurado, Viability study of a fc-battery-sc tramway controlled by equivalent consumption minimization strategy, International Journal of Hydrogen Energy 37 (2012) 9368 - 9382.

27] L. Xu, J. Li, J. Hua, X. Li, M. Ouyang, Optimal vehicle control strategy of a fuel cell/battery hybrid city bus, International Journal of Hydrogen Energy 34 (2009) 7323 - 7333.

[28] MATLAB control system toolbox, http://uk.mathworks.com/ products/control/ 2016. Accessed: 2016-08-19.

[29] S. J. Moura, D. S. Callaway, H. K. Fathy, J. L. Stein, Tradeoffs between battery energy capacity and stochastic optimal power management in plug-in hybrid electric vehicles, Journal of Power Sources 195 (2010) 2979-2988.

[30] L. Xu, F. Yang, J. Li, M. Ouyang, J. Hua, Real time optimal energy management strategy targeting at minimizing daily operation cost for a plug-in fuel cell city bus, International Journal of Hydrogen Energy 37 (2012) 15380-15392.

[31] P. Tulpule, V. Marano, G. Rizzoni, Effects of different PHEV control strategies on vehicle performance, in: 2009 Ameri- can Control Conference, 2009, pp. 3950-3955. doi 10.1109/ACC . 2009.5160595

32] S. Njoya, O. Tremblay, L.-A. Dessaint, A generic fuel cell model for the simulation of fuel cell vehicles, in: Vehicle Power and Propulsion Conference, 2009. VPPC'09. IEEE, IEEE, 2009, pp. 1722-1729.

[33] L. Barelli, G. Bidini, A. Ottaviano, Optimization of a PEMFC/battery pack power system for a bus application, Applied Energy 97 (2012) 777-784

[34] Fuel Cell Handbook (Seventh Edition), Technical Report, EG \& G Technical Services, Inc., 2004. Contract No.DE-AM2699FT40575.

[35] O. Tremblay, L.-A. Dessaint, Experimental validation of a battery dynamic model for EV applications, World Electric Vehicle Journal 3 (2009) 1-10.

[36] Battery, http://uk.mathworks.com/help/physmod/sps/ powersys/ref/battery.html, 2016. Accessed: 2016-04-22.

[37] A. Foley, B. Tyther, P. Calnan, B. . Gallachir, Impacts of electric vehicle charging under electricity market operations, Applied Energy 101 (2013) 93 - 102. Sustainable Development of Energy, Water and Environment Systems.

[38] Y. He, M. Chowdhury, P. Pisu, Y. Ma, An energy optimization strategy for power-split drivetrain plug-in hybrid electric vehicles, Transportation Research Part C: Emerging Technologies 22 (2012) 29-41.

[39] J. R. Bartels, M. B. Pate, N. K. Olson, An economic survey of hydrogen production from conventional and alternative energy sources, International Journal of Hydrogen Energy 35 (2010) 8371-8384.

[40] R. Winkel, U. Weddige, D. Johnsen, V. Hoen, G. Papaefthymiou, Potential for Shore Side Electricity in Europe, Technical Report, ECOFYS Consultancy, 2015. Project number:TRANL14441. 